\title{
Frailty in the elderly: screening possibilities in Primary Health Care
}

\author{
Fragilidade no idoso: possibilidades de rastreio na Atenção Primária à Saúde \\ Fragilidad en el anciano: posibilidades de rastreo en la Atención Primaria de Salud
}

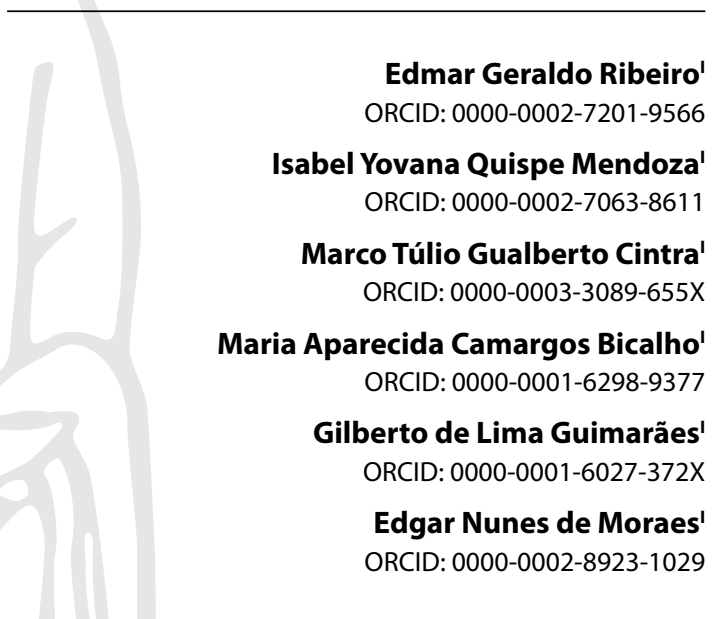

'Universidade Federal de Minas Gerais. Belo Horizonte, Minas Gerais, Brazil.

How to cite this article: Ribeiro EG, Mendoza IYQ, Cintra MTG, Bicalho MAC, Guimarães GL, Moraes EM. Frailty in the elderly: screening possibilities in Primary Health Care.

Rev Bras Enferm. 2022;75(2):e20200973. https://doi.org/10.1590/0034-7167-2020-0973

\section{Corresponding author: \\ Edmar Geraldo Ribeiro \\ E-mail: edmargribeiro@gmail.com}

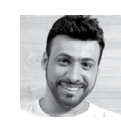

EDITOR IN CHIEF: Antonio José de Almeida Filho ASSOCIATE EDITOR: Álvaro Sousa

\begin{abstract}
Objectives: to evaluate two instruments for screening frailty in the elderly in Primary Health Care. Methods: this is an observational, cross-sectional study, with a quantitative approach, with 396 elderly people. SPSS software helped to perform the statistical analyses. The study used the kappa coefficient and Spearman's correlation. Results: the kappa coefficient between the Clinical-Functional Vulnerability Index 20 and the Edmonton Frailty Scale was 0.496, considered moderate. There was a positive and significant correlation $(r=0.77 ; p<0.001)$ between the frailty conditions and the total score of the two instruments. Conclusions: when this article assessed fragility through the kappa coefficient, both instruments presented positive correlation and agreement. However, the identification of frailty was higher when it used the Edmonton Frailty Scale. Descriptors: Elderly; Aging; Frailty; Primary Health Care; Geriatric Evaluation.
\end{abstract}

\section{RESUMO}

Objetivos: avaliar dois instrumentos de rastreio de fragilidade no idoso na Atenção Primária à Saúde. Métodos: trata-se de um estudo observacional, do tipo transversal, com abordagem quantitativa, com 396 idosos. As análises estatísticas foram realizadas com auxílio do software SPSS. Foram usados o coeficiente kappa e a correlação de Spearman. Resultados: o coeficiente kappa entre o Índice de Vulnerabilidade Clínico Funcional 20 e a Escala de Fragilidade de Edmonton foi de 0,496 , considerado moderado. Houve correlação positiva e significante $(r=0,77 ; p<0,001)$ entre as condições de fragilidade e a pontuação total dos dois instrumentos. Conclusões: ao avaliar a fragilidade, ambos os instrumentos apresentaram correlação positiva e concordância quando verificados pelo coeficiente kappa. Entretanto, a identificação da fragilidade foi superior quando utilizada a Escala de Fragilidade de Edmonton.

Descritores: Idoso; Envelhecimento; Fragilidade; Atenção Primária à Saúde; Avaliação Geriátrica.

\section{RESUMEN}

Objetivos: evaluar dos instrumentos de rastreo de fragilidad en el anciano en la Atención Primaria de Salud. Métodos: se trata de un estudio observacional, del tipo transversal, con abordaje cuantitativo, con 396 ancianos. Los análisis estadísticos fueron realizados con auxilio del software SPSS. Fueron usados el coeficiente kappa y la correlación de Spearman. Resultados: el coeficiente kappa entre el Índice de Vulnerabilidad Clínico Funcional 20 y la Escala de Fragilidad de Edmonton fue de 0,496 , considerado moderado. Hubo correlación positiva y significante $(r=0,77 ; p<0,001)$ entre las condiciones de fragilidad y la puntuación total de los dos instrumentos. Conclusiones: al evaluar la fragilidad, ambos los instrumentos presentaron correlación positiva y concordancia cuando verificados por el coeficiente kappa. Entretanto, la identificación de la fragilidad fue superior cuando utilizada la Escala de Fragilidad de Edmonton. Descriptores: Anciano; Envejecimiento; Fragilidad; Atención Primaria de Salud; Evaluación Geriátrica. 


\section{INTRODUCTION}

Morbidity and mortality rates in the health system reflect the undeniable growth of the elderly population in Latin American countries. In Brazil, it is a growing phenomenon and is associated, among other aspects, with the reduction in the fertility rate and increase in life expectancy ${ }^{(1-2)}$. According to the Brazilian Institute of Geography and Statistics (IBGE), in 2000, the Brazilian population over 60 years of age was 14.5 million people, representing an increase of $35.5 \%$ compared to 10.7 million in 1991. Currently, this number exceeds 29 million, and studies estimate that there will be approximately 73 million people aged 60 and over by 2060 , which would represent an increase of $160 \%$.

Aging is considered a sequential, individual, cumulative, and irreversible process of deterioration of the organism, which can compromise physical, mental, and/or social health. It is often related to the higher prevalence of chronic non-communicable diseases (NCDs), which can influence the emergence of physical limitations, cognitive losses, depressive symptoms, sensory decline, accidents, falls, urinary incontinence, and social isolation called geriatric syndromes ${ }^{(1,3)}$.

The association between NCDs and geriatric syndromes can impact the clinical and functional capacity of the elderly, making them vulnerable and later fragile. Therefore, screening for frailty in the elderly allows early interventions to prevent or slow down this fragility, which is potentially modifiable. In the context of Primary Health Care (PHC), the factors associated with frailty in the elderly can strongly reduce impacts on the health system through public policies that organize an integrated care model focused on this portion of the population ${ }^{(4)}$. Given this scenario, the discussion and screening of frailty in the elderly population at the first level of health care becomes relevant $\mathrm{t}^{(1,3-5)}$.

The term "fragility" is polysemic in the scientific literature. However, we can identify some of its constituent elements such as decreased reserve and resistance to stressful factors of the organism, leading to a reduction in the capacity to maintain homeostasis, greater dependence, increased risk of mortality, and adverse health events such as falls, injuries, acute diseases, hospitalizations, institutionalization. It is an inseparable whole, multidimensional in nature, which reduces the adaptation to biopsychosocial aggressions. Therefore, any strategy aimed at serving this clientele should consider the multidimensional aspects affected. Thus, in public health, the concept of fragility must be broad so that the primary care network can respond to the needs of this population and, with this, maintain and promote its autonomy and independence ${ }^{(1,3-6)}$.

International studies with the elderly from communities in different countries describe the prevalence of frailty. For example, a meta-analysis study that included 29 publications and 43,083 community elders in Latin America and the Caribbean identified a mean predominance of the fragility of $19.6 \%$, ranging from $7.7 \%$ to $42.6 \% \%^{(7)}$. In Brazil, in a recent study including the elderly of a community, the prevalence of frail individuals was $5.2 \%$, and that of pre-frail individuals was $49.9 \%{ }^{(8)}$.

Studies expect that the prevalence of frail elderly increase considerably with population dynamics projected for the coming years ${ }^{(9)}$. The evaluation of the main determinants of health of the elderly in PHC and, consequently, its correct stratification, is essential for the guidance of health professionals in the elaboration of a care plan, the indication of multidisciplinary interventions, identification of aspects that need a more detailed investigation, and direction to the geriatric physician appointment. This approach aims to maintain and improve the autonomy and independence of the elderly ${ }^{(10)}$.

A systematic review study that aimed to identify instruments for the detection of frailty in the elderly, characterize its components, application scenarios, and the ability to identify pre-frailty and psychometric properties showed that the evaluation of frailty predominantly follows a one-dimensional approach, that is, it only evaluates physical health ${ }^{(11)}$. The Clinical-Functional Vulnerability Index 20 (CFVI-20), recently created by a multi-professional reference team in elderly health care, and the Edmonton Frailty Scale (EFS), developed by the Canadian Initiative on Frailty and Aging group, are instruments that cover multidimensionality ${ }^{(6,12)}$.

When evaluating the psychometric properties of CFVI-20 in PHC, the study used the Item Response Theory (IRT), which estimates the latent trait. The results showed an overall Cronbach's alpha of 0.73 . All items had a positive biserial correlation with the latent variable (fragility); the first factor explained $20 \%$ of the total variance, and the parameters for construct validity and concurrent criterion were considered adequate ${ }^{(13)}$.

The Brazilian version of EFS has an interobserver coefficient $(\mathrm{kappa}=0.81)$ and intraobserver $(\mathrm{kappa}=0,83)$. The interobserver and intraobserver intraclass correlation coefficient is equal to 0.87 , and Alpha shows the following results: $\mathrm{T} 1, \mathrm{a}=0.62 ; \mathrm{A} 1, \mathrm{a}=$ 0.62 ; and $\mathrm{T} 2, \mathrm{a}=0.54^{(12)}$.

In this context, the assessment of fragility in $\mathrm{PHC}$ is considered a challenge. Understanding the interaction of physical, psychological, social, and environmental dimensions to determine frailty should be the premise of care for the elderly. Researchers believe that identifying points of convergence and divergence between the CFVI-20 and EFS allows the decision-making regarding its application by PHC professionals. Given the above, the research asks the question: What are the dimensions of convergence and divergence between the EFS and CFVI-20 in the screening of frailty in the elderly?

\section{OBJECTIVES}

To evaluate two instruments for screening frailty in the elderly in Primary Health Care.

\section{METHODS}

\section{Ethical aspects}

The study complied with resolution $466 / 12$ of the National Health Council (NHC) and obtained approval from the Research Ethics Committee of the Federal University of Minas Gerais (CEP/ UFMG) and the Municipal Health Department of Belo Horizonte (CEP/SMSA-BH).

\section{Design, period and place of study}

This is an observational study, cross-sectional, with a quantitative approach, conducted in 12 basic health units (BHU) of PHC 
in the South-Central Region of Belo Horizonte/State of Minas Gerais (BH/MG), Brazil. The study followed the guidelines of the Report Guideline STROBE for publication of observational studies $^{(14)}$. The South-Central Region is the center of commerce and services of Belo Horizonte including 49 neighborhoods divided into five territories of shared management. It has a population of 283,776 residents and is the largest group of people over 60 years of the capital, totaling 51,715 individuals ${ }^{(15)}$. Data collection took place in the period from January to April 2018.

\section{Sample, criteria of inclusion and exclusion}

The study calculated the sample to be possible to extend the results obtained to the population of elderly residents in the Central-South Region of BH/MG. It used a method to estimate proportions for finite populations randomly, with proportional allocation by $\mathrm{BHU}^{(16)}$. Considering a margin of error of $5 \%$ and $\mathrm{a}$ significance level of $5 \%$, the minimum sample required for the study was 381 elderly. And considering the $20 \%$ increase in losses, the sample size would be 458 elderly. Thus, the study invited 458 elderly, of which 62 refused to participate, totaling a final sample of 396 elderly people.

The sample was probabilistic and recruited participants through simple random selection using the Microsoft Excel program (version 2016). Initially, the research asked managers of the BHU to list the elderly registered in the Family Health Strategy (FHS) and the Community Health Agents Program (CHAP).

The inclusion criteria adopted were: to be aged 60 years or over, to be resident in the South-Central Region of Belo Horizonte/ Minas Gerais, and to be duly registered in the FHS and/or CHAP. Exclusion criteria: do not attend the evaluation at the scheduled date and times, and do not have telephone contact in the list of registered seniors.

\section{Study protocol}

A member of the research team previously scheduled the evaluations via telephone call. The member explained all the elderly about the research, and if they agreed to participate, signed the Informed Consent Form (ICF).

For data collection, the study used the following instruments: Mini-Mental State Examination (MMSE)(17), sociodemographic questionnaire, Edmonton Frailty Scale (EFS) ${ }^{(12)}$, and ClinicalFunctional Vulnerability Index 20 (CFVI-20) ${ }^{(6)}$. The application of the research protocol lasted an average of 30 minutes. The collection took place from Monday to Friday, according to the availability of the survey participant.

Initially, the elderly underwent a cognitive screening evaluation by applying the MMSE. The study defined the cut-off points according to the participant's education: illiterate, 13 points; with low or medium education, 18 points; and with a high level of education, 26 points ${ }^{(17-18)}$. If the MMSE was below the cut-off point, the researcher interviewed the companion due to the suspicion of cognitive deficit.

The researchers created an instrument to collect the following sociodemographic data: gender, age, marital status, housing, education, religion, if he had a caregiver, income, and current occupation. They also obtained information from the electronic medical record, such as the name of the user, medical record number, date of birth, telephone number, the micro area of residence, and the mother's name. A nurse collected the data and previously trained collaborators under the coordination of the principal investigator.

Researchers used two instruments on fragility. One was the Edmonton Frailty Scale (EFS), created in Canada, developed to detect frailty in the elderly, adapted, and validated in several countries, including Brazil. The EFS addresses multidimensional aspects related to frailty, which is composed of 11 questions divided into nine domains, with a total of 17 points, meaning: from 0 to 4 , the elderly do not present frailty; between 5 and 6 points, the elderly presents vulnerability; from 7 to 8 , mild frailty; from 9 to 10 , moderate frailty; and 11 or more points, severe frailty ${ }^{(12)}$.

The study adopted other instrument called Clinical-Functional Vulnerability Index-20 (CFVI-20), used for interdisciplinary screening. It contemplates multidimensional aspects of the health condition of individuals aged 60 years or older and consists of twenty questions distributed in eight sections on various health domains and health-related factors. It has a total of 40 points: from 0 to 6 points, the elderly person is considered robust; from 7 to 14 points, the elderly person is at risk of frailty; and 15 points or more, the elderly person is fragile ${ }^{(6)}$.

\section{Analysis of results and statistics}

In the description of the qualitative variables of the sample, the study used absolute and relative frequencies. For data analysis, the study divided the results of the dependent variable into two levels: for EFS, without frailty (final score $\leq 6$ ) and with frailty (final score $>6$ ); and for CFVI-20, without frailty (final score $<15$ ) and with frailty (final score $\geq 15$ ). The kappa coefficient verified the agreement degree between both instruments, and the study considered the following values: 0 (lack of agreement), 0-0.19 (poor) 0.20-0.39 (weak), 0.30-0.59 (moderate), 0.60-0.79 (substantial), and $\geq 0.80$ (almost complete). For the correlation analysis between the condition of the fragility of the two instruments, the study used Spearman's correlation. In this case, it considered the values $r$ from 0.10 to 0.30 (weak); from 0.40 to 0.6 (moderate); from 0.70 to 1 (strong). The study adopted significance values of $a<0.05$ (19). The analysis used the software SPSS (version 23).

\section{RESULTS}

Three hundred and ninety-six elderly participated in this study, with a predominance of female (65.4\%), age group between 60 and 74 years $(64.81 \%)$, and mean age 71.8 years. The mean number of years of study was 7.13 (SD \pm 5.25$) .43 .69 \%$ of the participants were married or had a stable union, $80.81 \%$ had their own home, and $91.33 \%$ were retired with an average salary of a minimum wage $(\mathrm{R} \$ 1,045.00)$. The MMSE mean was $24.35(\mathrm{SD} \pm 4.48)$ points, and, considering the cut-off points of this examination, $17.92 \%$ of the elderly had suspected cognitive deficit.

Regarding the comparison of the frailty of the elderly evaluated, both instruments presented $97.3 \%$ of the elderly without frailty and $44.2 \%$ with frailty. The degree of agreement of the 
kappa coefficient between the two instruments was 0.496 , according to Table 1.

According to the CFVI-20, the final score average of the frailty classification was 8.22 ( $S D \pm 5.97$ ) with a range of 0 to 36 points, and the EFS was $4.56(S D \pm 2.66)$, with a range of 0 to 13 points. Analyzing the correlation between the total score of CFVI-20 and EFS, the study found a positive and significant correlation $(r=$ 0.77; $p=0.001$ ), according to data from Table 2 .

Tables 3 and 4 present the results of the CFVI-20 and EFS questionnaires, respectively.

Table 1 - Comparison between the frailty condition of the Clinical-Functional Vulnerability Index 20 and the Edmonton Frailty Scale, 2018

\begin{tabular}{|c|c|c|c|c|c|c|c|}
\hline & \multicolumn{6}{|c|}{ EFE } & \multirow{3}{*}{ kappa* } \\
\hline & \multicolumn{2}{|c|}{ No fragility } & \multicolumn{2}{|c|}{ With fragility } & \multicolumn{2}{|c|}{ Total } & \\
\hline & $\mathbf{n}$ & $\%$ & $\mathbf{n}$ & $\%$ & $\mathbf{n}$ & $\%$ & \\
\hline CFVI-20 & & & & & & & 0.496 \\
\hline No fragility & 293 & 97.3 & 53 & 55.8 & 346 & 87.4 & \\
\hline With fragility & 08 & 2.7 & 42 & 44.2 & 50 & 12.6 & \\
\hline Total & 301 & 100.0 & 95 & 100.0 & 396 & 100.0 & \\
\hline
\end{tabular}

Table 2 - Correlation between the total scores of the Clinical-Functional Vulnerability Index and the Edmonton fragility scale, 2018

\begin{tabular}{lcc}
\hline Variables & $\begin{array}{c}\text { Final score - EFS } \\
\mathbf{r}(\boldsymbol{p} \text { value })^{\mathbf{1}}\end{array}$ & $\begin{array}{c}\text { Final score }- \text { CFVI } \\
\mathbf{r}(\boldsymbol{p} \text { value })^{\mathbf{1}}\end{array}$ \\
\hline $\begin{array}{l}\text { Final score-CFVI-20 } \\
\text { Total score-EFS }\end{array}$ & $\begin{array}{c}0.77(0.001) \\
-\end{array}$ & - \\
\hline
\end{tabular}

$\overline{\text { EFS - Edmonton Frailty Scale; CFVI-20 - Clinical-Functional Vulnerability Index 20; 1Spearman }}$ correlation (value of $p$ ).

Table 3 - Descriptive analysis of the variables related to the questionnaire Clinical-Functional Vulnerability Index 20, 2018

\begin{tabular}{|c|c|c|}
\hline Variables & $\mathbf{n}$ & $\%$ \\
\hline \multicolumn{3}{|l|}{ Age } \\
\hline \multicolumn{3}{|l|}{ Age $(n=395)$} \\
\hline 60 to 74 years & 256 & 64.81 \\
\hline 75 to 84 years & 114 & 28.86 \\
\hline 85 years or older & 25 & 6.33 \\
\hline \multicolumn{3}{|c|}{ Self-perception of Health } \\
\hline \multicolumn{3}{|c|}{ Self-perception of Health $(n=396)$} \\
\hline Excellent & 39 & 9.85 \\
\hline Very good & 50 & 12.63 \\
\hline Good & 187 & 47.22 \\
\hline Regular & 108 & 27.27 \\
\hline Bad & 12 & 3.03 \\
\hline \multicolumn{3}{|c|}{ Instrumental daily life activity } \\
\hline \multicolumn{3}{|c|}{$\begin{array}{l}\text { Did you stop shopping because of your health or } \\
\text { physical condition? }(n=396)\end{array}$} \\
\hline No & 341 & 86.11 \\
\hline Yes & 55 & 13.89 \\
\hline \multicolumn{3}{|c|}{$\begin{array}{l}\text { Have you stopped controlling your money, } \\
\text { spending or paying bills because of your health or } \\
\text { physical condition? }(n=396)\end{array}$} \\
\hline No & 366 & 92.42 \\
\hline Yes & 30 & 7.58 \\
\hline \multicolumn{3}{|c|}{$\begin{array}{l}\text { Have you stopped doing small housework because } \\
\text { of your health or physical condition? }(n=395)\end{array}$} \\
\hline No & 363 & 91.90 \\
\hline Yes & 32 & 8.10 \\
\hline
\end{tabular}

Table 3 (concluded)

Variables

$\%$

Basic daily living activity

Did you stop bathing alone because of your health or physical condition? $(n=396)$

No

Yes

Cognition

Are you forgetting things? $(n=396)$

No

$15 \quad 3.79$

Yes

154

38.89

Is this forgetfulness getting worse in recent months? $(n=396)$

No

242

61.11

Yes

Is this forgetfulness preventing the realization of some activity of everyday life? $(n=396)$

No

Yes

11128.03

Mood

Were you sad or hopeless? $(n=396)$

No

Yes

Lost interest or pleasure in previously pleasurable activities? $(n=396)$

No

Yes

Mobility

Are you unable to raise your arms above shoulder level? $(n=396)$

No

Yes

$380 \quad 95.96$

Are you unable to handle small objects? $(n=396)$

No

Yes

36892.93

$28 \quad 7.07$

$209 \quad 52.78$

$187 \quad 47.22$

$312 \quad 78.79$

$84 \quad 21.21$

Has any of the four conditions: unintentional weight

loss; BMI less than $22 \mathrm{~kg} / \mathrm{m} 2$; calf circumference

less than $31 \mathrm{~cm}$ or walking speed greater than 5 seconds? $(n=392)$

No

Yes

$285 \quad 72.70$

$107 \quad 27.30$

Is the difficulty of walking able to prevent the realization of some activity of everyday life? $(n=392)$

No

Yes

$358 \quad 91.33$

$34 \quad 8.67$

Have you had two or more falls in the last year? ( $n=395)$

No

Yes

$296 \quad 74.94$

$99 \quad 25.06$

Do you lose urine or feces, unintentionally, at some point? $(\mathrm{n}=396)$

No

Yes

$201 \quad 50.76$

$195 \quad 49.24$

Communication

Vision problems $(\mathrm{n}=396)$

No

Yes

Hearing problems $(n=396)$

No

Yes

$345 \quad 87.12$

$51 \quad 12.88$

$356 \quad 89.90$

$40 \quad 10.10$

Multiple Comorbidities

Do you have any of three conditions: five or more chronic diseases; regular use of five or more medications a day; recent hospitalization or in the last six months? $(\mathrm{n}=396)$

No

$227 \quad 57.32$

Yes

16942.68 
Table 4 - Descriptive analysis of the variables on the Edmonton Fragility Scale, 2018

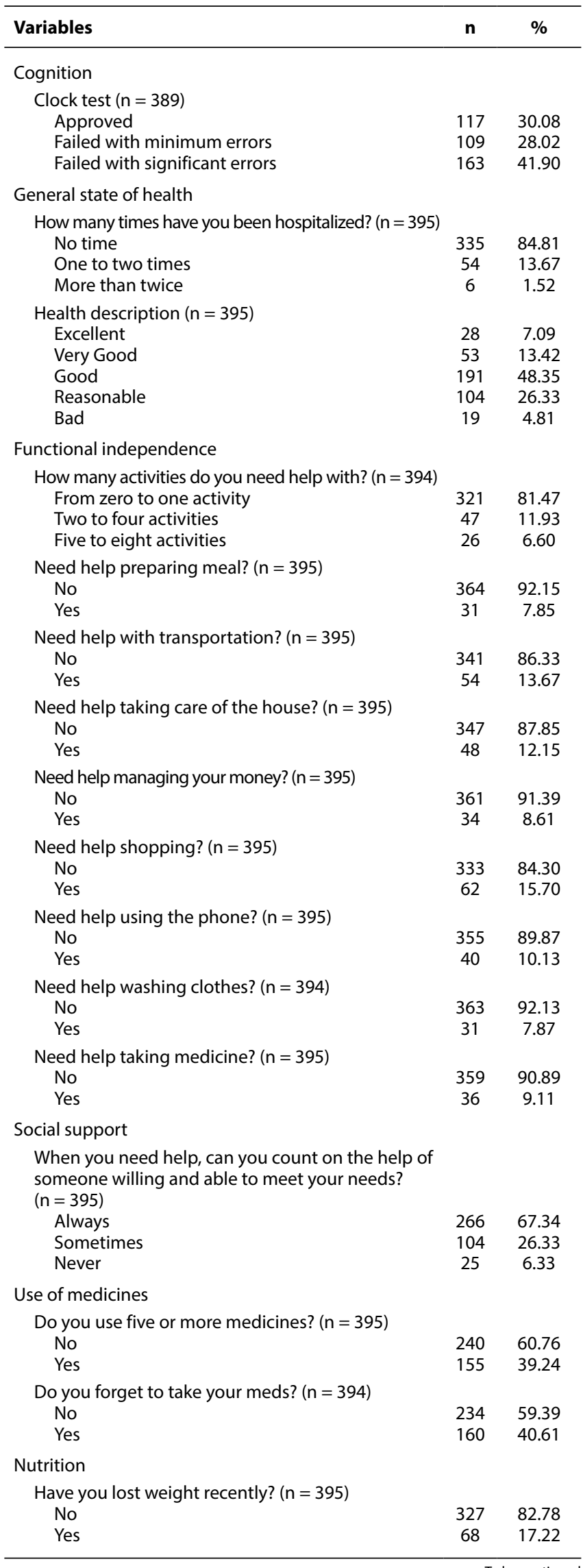

Table 4 (concluded)

\begin{tabular}{llc}
\hline Variables & $\mathbf{n}$ & $\%$ \\
\hline Mood & & \\
$\quad$ Do you often feel sad or depressed? $(\mathrm{n}=395)$ & & \\
$\quad$ No & 249 & 63.04 \\
$\quad$ Yes & 146 & 36.96 \\
Continence & & \\
$\quad$ Do you have a problem losing control of your & & \\
urine? ( $\mathrm{n}=395)$ & 216 & 54.68 \\
$\quad$ No & 179 & 45.32 \\
$\quad$ Yes & & \\
Functional performance & & \\
$\quad$ Stand and walk test $(\mathrm{n}=392)$ & 251 & 64.03 \\
$\quad$ From 0 to 10 seconds & 110 & 28.06 \\
$\quad$ From 11 to 20 seconds & 31 & 7.91 \\
$\quad$ More than 20 seconds & & \\
\hline
\end{tabular}

\section{DISCUSSION}

The results of the sociodemographic characterization of this study are similar to those of other Brazilian studies ${ }^{(20-21)}$. The agreement analysis kappa refers to the ability to measure identical results, applied to the same subject/phenomenon, either by different instruments, by the same instrument at different moments, by different evaluators, or by some combination of these situations ${ }^{(17)}$. In the present study, the results of the kappa coefficient demonstrated a moderate and statistically significant agreement between CFVI-20 and EFS, which can be explained by the differences between the prevalence of frailty in both instruments. The representativeness of the analyzed class influences the agreement indicators, which requires the maximum homogeneity between the subgroups ${ }^{(22)}$. Thus, these results point to the need to conduct new studies to confirm the agreement index between both instruments.

When the study analyzed the correlation between the total score of the CFVI-20 and the EFS, it presented a positive and significant correlation. This result indicates that the two instruments have similarity in the distribution of their scores, and it is linear, that is, the higher the final score of the CFVI-20, the higher the total score of the EFS tends to be and vice versa. In the literature, there are no studies on the correlation of EFS and CFVI-20, and the justification may be the recent application of CFVI-20 in research. Researchers believe that as it is an instrument with only twenty items, people previously trained and not necessarily specialists in the area, can apply it easily and quickly, making it feasible to be used in PHC.

The result of this study corroborates a study conducted at the Elderly Reference Center (CRI) of the Hospital das Clínicas of the Federal University of Minas Gerais (Jenny de Andrade Faria Institute of Senior (are) and in the PHC, which evidenced a high degree of positive correlation between the CFVI-20 and the broad geriatric evaluation ${ }^{(6)}$.

Previous studies used EFS to estimate the prevalence of frailty in elderly residents of the community in Ribeirão Preto (São Paulo) ${ }^{(23)}$, Montes Claros (Minas Gerais) ${ }^{(24)}$ and Embu (São Paulo) ${ }^{(25)}$. In the present study, the prevalence of frailty was lower than the results of national studies, inferring that the elderly participants of this study maintain their functionality. However, the percentage of frailty was higher when the study compared EFS to CFVI-20. This result can be attributed to the high rate of failure of the elderly in the clock test. It is worth noting that the classification of frailty 
according to the EFS is categorized as mild, moderate, and severe. In CFVI-20, there is only one classification, frail elderly.

When the study analyzed the self-perception of the health of the elderly, most participants consider it good, which is significant since as it is an indicator of the quality of life and health, precedes functional decline and death, and demonstrates the impact of chronic-degenerative diseases on the physical, social and mental well-being of the elderly ${ }^{(26)}$.

The impairment in daily living activities (DLAs) was similar in both instruments. However, most of the elderly reported needing assistance for a DLA, when EFS assessed the functional capacity. Thus, the results indicate that the elderly participants of the research maintain the skills of mobility, maintenance of the environment, and, above all, of social participation independently ${ }^{(27)}$.

In the assessment of mood by both instruments, it is assumed that, in the study participants, feelings of sadness, discouragement, and hopelessness do not have repercussions on fragility. However, the monitoring of the elderly with depressive symptoms in this population has crucial importance. In a study conducted with elderly registered in the Family Health Units of João Pessoa, State of Paraíba, Brazil, depressive symptoms were lower than in the present study. The authors conclude that happiness is an indicator of well-being and can act as a protective factor against depressive symptoms ${ }^{(28)}$.

On the other hand, evaluating urinary incontinence, the proportion of positive responses by the elderly was representative for both instruments. According to the International Continence Society (ICS), urinary incontinence (UI) is a condition in which complaints of any involuntary loss of urine occur. The causes are multifactorial, and the consequences are changes in the quality of life of the population. International systematic review and meta-analysis study indicates prevalence similar to that found in this study ${ }^{(29)}$. In Brazil, we still do not have precise statistical data in this regard since epidemiological studies are scarce ${ }^{(30)}$.

As for cognition, it is worth noting that the instruments use different evaluation parameters. The CFVI-20 uses only three questions to assess cognition, and EFS uses the clock test. The rate of cognitive decline screening was higher when the study used the EFS, which can be a result of the assessment of visuospatial skills, constructive skills, and executive functions of the instrument. Therefore, the study leads to the conclusion that the complexity of cognitive assessment is enlarged when it compares this scale to the CFVI- 20 .

Aging brings many psychological changes and, among them is the loss of muscle mass and strength, which directly affects the quality of life of elderly individuals. Thus, in the items of mobility and functional independence, participants presented similar results for both instruments. These items refer to the ability of the elderly to correspond to daily demands and have a significant association with a greater risk of frailty ${ }^{(31)}$.
Concerning multiple comorbidities, both instruments show that the elderly have polypharmacy, whose occurrence is frequent in the elderly population and is often associated with polypathology ${ }^{(23)}$. Studies prove that the multiple comorbidities are linked to clinical-functional decline and subsequent frailty, mainly when evaluated in $\mathrm{PHC}$, as described in the literature ${ }^{(4)}$. Regarding the history of hospitalizations, it is not possible to compare this item between the instruments since EFS does not determine the time.

The early identification of the elderly most vulnerable to the process of fragility can provide the health team in $\mathrm{PHC}$ with the possibility of adopting protective measures to prevent, slow, or recover the autonomy and independence of this portion of the population.

\section{Study limitations}

It is essential to consider some limitations of this study, such as the sample belongs to only one region of the municipality. Therefore, there is a generalization limit.

The increase in frail elderly in advanced ages suggests a progressive condition of frailty, associated with loss of functional capacity, disabling health problems, inadequate social support, among others ${ }^{(32)}$. In the present study, the majority of the sample corresponds to the younger elderly, which may become a limitation for the analysis of frailty screening in PHC.

\section{Contributions to the fields of Nursing, Health or Public Policy}

This study contributes to the strengthening and direction of integral health policies and actions for the elderly population in $\mathrm{PHC}$ through the understanding and focusing on the screening of frailty at this level of health care. The early identification of the elderly most vulnerable to the process of fragility can provide the $\mathrm{PHC}$ health team with the possibility of adopting measures to prevent, slow, or recover the autonomy and independence of this portion of the population. Both are multidimensional evaluation instruments. However, the CFVI-20, as a tool for quick and easy screening application by any health professional, can be adopted in care places where there is a shortage of time and specialized human resources, such as in PHC.

\section{CONCLUSIONS}

This study made it possible to evaluate frailty in the elderly. Both instruments presented similar characteristics concerning dimensions. The prevalence of frailty was higher when the study used the EFS, which may be related to the "cognition" aspect evaluated by this instrument. In addition, CFVI-20 and EFS showed moderate agreement by the kappa coefficient and positive correlation by Spearman's test.

\section{REFERENCES}

1. Leite BC, Oliveira-Figueiredo DST, Rocha FL, Nogueira MF. Multimorbidity due to chronic noncommunicable diseases in older adults: a population-based study. Rev Bras Geriatr Gerontol. 2019;22(6):e190253. https://doi.org/10.1590/1981-22562019022.190253

2. Instituto Brasileiro de Geografia e Estatística (IBGE). Censo [internet]. 2010. [cited 2020 Jul ]. Available from: www.ibge.gov.br. 
3. Venturini C, Sampaio RF, Moreira BS, Ferriori E, Neri AL, Lourenço RA, Lustosa LP. A multidimensional approach to frailty compared with physical phenotype in older Brazilian adults: data from the FIBRA-BR study. BMC Geriatr. 2021;21:246. https://doi.org/10.1186/ s12877-021-02193-y

4. Maia LC, Moraes EN, Costa SM, Caldeira AP. Fragilidade em idosos assistidos por equipes da atenção primária. Cienc Saude Colet. 2020;25(12):5041-50. https://doi.org/10.1590/1413-812320202512.04962019

5. Travers J, Romero-Ortuno R, Bailey J, Cooney MT. Delaying and reversing frailty: a systematic review of primary care interventions. British J Gen Pract. 2019;69(678):e61-e69. https://doi.org/10.3399/bjgp18X700241

6. Moraes EN, Carmo JA, Lanna FM, Azevedo RS, Machado CJ, Romero DEM. Clinical-Functional Vulnerability Index-20 (IVCF-20):rapid recognition of frail older adults. Rev Saúde Pública. 2016;50:81. https://doi.org/10.1590/s1518-8787.2016050006963

7. Binotto MA, Lenardt MH, Rodriguez-Martinez MC. Physical frailty and gait speed in community elderly: a systematic review. Rev Esc Enferm USP. 2018;52: https://doi.org/10.1590/s1980-220×2017028703392

8. Lourenço RA, Moreira VG, Banhato EFC, Guedes DV, Silva KCA, Delgado FEF, Marmora CHC. Prevalence of frailty and associated factors in a communitydwelling older people cohort living in Juiz de Fora, Minas Gerais, Brazil: Fibra-JF Study. Cienc Saude Colet. 2019;24(1):35-44. https://doi.org/10.1590/1413-81232018241.29542016

9. Stuart GB, Silvia E, Giorguli S, Sergei S. Prospective measures of aging for Central and South America. Plos One. 2020;24. https://doi. org/10.1371/journal.pone.0236280

10. Freitas FFQ, Rocha AB, Moura ACM, Soares SM. Older adults frailty in Primary Health Care: a geoprocessing-based approach. Cien Saude Colet. 2020;25(11):4439-50. https://doi.org/10.1590/1413-812320202511.27062018

11. Faller JW, Pereira DDN, de Souza S, Nampo FK, Orlandi FS, Matumoto S. Instruments for the detection of frailty syndrome in older adults: a systematic review. PLoS One. 2019;29;14(4):e0216166. https://doi.org/10.1371/journal.pone.0216166

12. Fabrício-wehbe SCC, Schiaveto FV, Vendrusculo TRP, Haas VJ, Dantas RAS, Rodrigues RAP. Cross-cultural adaptation and validity of the "Edmonton Frail Scale - EFS" in a Brazilian elderly sample. Rev Latino-Am Enfermagem. 2009;17(6):1043-49. https://doi.org/10.1590/ S0104-11692009000600018

13. Ribeiro EG, Mendoza IYQ, Moraes EN, Alvarenga MRM, Cintra MTG, Guimarães GL. Psychometric properties of the clinical-functional vulnerability index - 20 in Primary Health Care. Rev Min Enferm. 2020. https://doi.org/10.5935/1415.2762.20200069

14. Pacheco RL, Martimbianco ALC, Garcia CM, Logulho P, Riera R. Guidelines para publicação de estudos científicos. Parte 2: como publicar estudos observacionais (coorte, caso-controle e transversal). Diagn Tratamento. 2017;22(3):121-6. Available from: http://docs.bvsalud.org/ biblioref/2017/08/848018/rdt_v22n3_121-126.pdf

15. Secretaria de Estado da Saúde de Belo Horizonte (SES-MG). Região Centro-Sul [Internet]. 2018. [cited 2021 May 20]. Available from: http:// www.saude.mg.gov.br

16. Bolfarine H, Bussab W. O. Elementos de Amostragem. São Paulo: Blucher, 2005. 290 p.

17. Bertolucci PHF, Brucki SMD, Campacci SR, Juliano Y. O Mini-Exame do estado mental em uma população geral: impacto da escolaridade. Arq Neuro-Psiquiatr. 1994;52(1):1-7. https://doi.org/10.1590/S0004-282X1994000100001

18. Lu L, Chen L, Wu W, Wang Y, Liu Z, Xu J, et al. Consistency and applicability of different brief screen instrument of cognitive function in elderly population. BMC Neurol. 2021;21:95. https://doi.org/10.1186/s12883-021-02048-4

19. Dancey C, Reidy J. Estatística sem matemática para psicologia. Penso; 7a edição. 2018. 624p.

20. Ceccon RF, Vieira JES, Brasil CCP, Soares KG, Portes VM, Garcia JCAS. Envelhecimento e dependência no Brasil: características sociodemográficas e assistenciais de idosos e cuidadores. Ciênc Saúde Colet. 2021;26(1):17-26. https://doi.org/10.1590/1413-81232020261.30352020

21. Alves VMC, Soares VN, Oliveira D, Fernandes PT. Sociodemographic and psychological variables, physical activity and quality of life in elderly at Unati Campinas, São Paulo. Fisioter Mov. 2020;33:e003310. https://doi.org/10.1590/1980-5918.033.ao10

22. Souza AC, Alexandre NMC, Guirardello EB. Propriedades psicométricas na avaliação de instrumentos: avaliação da confiabilidade e da validade. Epidemiol Serv Saúde. 2017;26(3):649-59. https://doi.org/10.5123/s1679-49742017000300022

23. Nunes DP, Duarte YA, Santos JL, Lebrão ML. Screening for frailty in older adults using a self-reported instrument. Rev Saúde Pública. 2015;49:1-9. https://doi.org/10.1590/S0034-8910.2015049005516

24. Carneiro JA, Ramos GCF, Barbosa ATF, Mendonça JMG, Costa FM, Caldeira AP. Prevalência e fatores associados à fragilidade em idosos não institucionalizados. Rev Bras Enferm. 2016;69(3):435-42. https://doi.org/10.1590/0034-7167.2016690304i

25. Fernandes HCL, Gaspar JC, Yamashita CH, Amendola F, Alvarenga MRM, Oliveira MMC. Avaliação da fragilidade de idosos atendidos em uma unidade da Estratégia Saúde da Família. Texto Contexto Enferm. 2013;22(2):423-31. https://doi.org/10.1590/S0104-07072013000200019

26. Carneiro JA, Gomes CAD, Durães W, Jesus DR, Chaves KLL, Lima CA, et al. Negative self-perception of health: prevalence and associated factors among elderly assisted in a reference center. Ciênc Saúde Colet. 2020;25:(3). https://doi.org/10.1590/1413-81232020253.16402018

27. Maia LC, Colares TFB, Moraes EN, Costa SM, Caldeira AP. Robust older adults in primary care: factors associated with successful aging. Rev Saúde Pública. 2020;54:35. https://doi.org/10.11606/s1518-8787.2020054001735

28. Abrantes GG, Souza GG, Cunha NM, Rocha HNB, Silva AO, Vasconcelos SC. Sintomas depressivos em idosos na atenção básica à saúde. Rev Bras Geriatr Gerontol. 2019;22(4). doi:10.1590/1981-22562019022.190023 
29. Batmani S, Jalali R, Mohammadi M, Bokaee S. Prevalence and factors related to urinary incontinence in older adults women worldwide: a comprehensive systematic review and meta-analysis of observational studies. BMC Geriatrics. 2021;21:212. https://doi.org/10.1186/ s12877-021-02135-8

30. Tomasi AVR, Santos SMA, Honório GJS, Locks MOH. Urinary incontinence in elderly people: care practices and care proposal in primary health care. Texto Contexto Enferm. 2017;26(2). https://doi.org/10.1590/0104-07072017006800015

31. Chang HK, Lee JY, Gil CR, Kim MK. Prevalence of sarcopenia in community-dwelling older adults according to simplified algorithms for sarcopenia consensus based on Asian Working Group for Sarcopenia. Clin Interv Aging. 2020;15:2291-99. https://doi.org/10.2147/CIA. S281131

32. Grden, CRB, Lenardt MH, Sousa JAV, Kusomota L, Dellaroza MSG, Betiolli, SE. Associação da síndrome da fragilidade física às características sociodemográficas de idosos longevos da comunidade. Rev Latino-Am Enfermagem. 2017;25. https://doi.org/10.1590/1518-8345.1770.2886 